\title{
The Difference between the Effects of Problem- based Learning Strategy and Conventional Strategy on Vocational School Students' Critical Thinking Skills in Civic Education
}

\author{
Ni Wayan Suarniati* \\ Pascasarjana, Universitas Negeri Malang \\ Universitas Wisnuwardhana Malang \\ I Wayan Ardhana, Nur Hidayah and Dany M. Handarini \\ Pascasarjana Universitas Negeri Malang
}

\begin{abstract}
This research aimed at examining the difference between the effects of problem-based learning strategy and conventional strategy on vocational school students' critical thinking skills in civic education. The research design used in this study was experimental design with nonequivalent pretest and posttest control group design. The data collection was conducted by using critical thinking instrument adapted from Watson Glasser Appraisal with the dimension of inference, recognition of assumptions, deduction, interpretation, and evaluation of argument. The data analysis technique utilized descriptive statistics and t-test. The analysis results showed that the mean of problem-based learning strategy was 50.79, while the mean of the conventional strategy was 28.79, and the $\mathrm{t}$-score for the difference between the effects of problem-based learning strategy and conventional strategy was 16.874 with the significance level of 0.000 . The result showed that there was a difference between the effects of problem-based learning strategy and conventional strategy on vocational school students' critical thinking skills in civic education subject.
\end{abstract}

Keywords: Problem-based Learning, Conventional Learning, Critical thinking skills.

\section{Introduction}

Critical thinking skills in the world of education are important because they determine the quality of schools, career, and students' attitude (Ruggiero, 2012).

*Corresponding author e-mail:ni.wayan.1301119@students.um.ac.id 
Students who think critically and creatively will be more ready to adapt in the rapidly changing world in fulfilling the career development. With regard to this research, there are three main reasons for the importance of crititical thinking development in the Vocational School (VS). First, recently, students are facing a more complex life situation, full of pressures, paradox, and uncertainty (Kemendikbud, 2016). The complex life situation needs a life competence development which not only depends on the subject learning service and management but also depends on a more specific service pedagogically through guidance and counseling. Second, the tight competence in the working world is getting more competitive with the vocational problems getting more and more complex (Neumark, D. \& Ann, 2003). The preliminary study result showed that the problems of Vocational graduates in Malang city related to working world namely, the jobs are not related to the skill learned, lack of motivation and skills in working, and not skillful in communicating and solving the problems. Meanwhile, the survey result of Guidance and counseling conducted by Handarini (2012) on 4300 Vocational school students in East Java showed that $50.12 \%$ of the students thought that critical thinking is needed for competition in the working world.

The third is accommodating a variety of accuracy analysis, well thought for deliberation in the democratic life (Siegel, 2010). Nowadays, the problems in the life of democracy in Indonesia are getting more complex, like threats on the unity of the nation, terrorism, corruption, intolerance, provocation, brawls, drugs, furthermore the rise of false news (hoax) in social media. Thus, schools need to create an environment that encourages the development of the needed skills including critical thinking to enable the students to do investigation, interpretation, and evaluation in which the point is the process of testing the argument and determining what is inappropriate and what is inappropriate (Ruggiero, V, 2012).

On the contrary, the school system in Indonesia is not capable of creating the learning environment that enables students to think critically, creatively, responsibly, and give chances to students to explore their imaginative ideas (Solaang, D, 2006).

It happens because the teachers only ask the students to learn and rarely to teach students the way of learning, thus it is difficult for them to solve problems, decide, think critically and creatively (Kusumaningtias, et al. 2013). In developing the critical thinking skills as a part of character education, Handarini (2017) wrote that most teachers and counselors stated that religion and civic education teachers are responsible to develop students' character, while the teachers of other subjects do not really behold of the responsibility for developing students' character. According to Bezanilla research, et al (2019) that there are three effective methods used by teachers for the development of critical thinking, namely reflection and argumentation oral and written, reading, analysis and synthesis of resources. 
Some studies related to critical thinking on teaching and learning have been widely conducted through various subjects such as mathematics (Widyatiningtyas, et al., 2015; Prayitno, A, 2016; Prayitno, A \& Suarniati, NW, 2017), engineering subjects (Awang, H, \& Ramly, I, 2008), physics subject (Sulaiman, F, 2013), economic subject (Yin, et al. 2011), and biology subject (Arslan,S, 2012). However, there has not been any research to develop critical thinking through civil education subject. Hidayah (2012) wrote that counselors are expected to work hand-in-hand and complete each other with teachers who use subjects as service context in facilitating the students'skill development. According to Fabiana (2015) critical thinkers are the key to democracy, so researchers and educators around the world focus on identifying and developing critical thinking strategies in the classroom. Meanwhile Harell (2019) writes that democratic learning is encouraged by focusing students' attention on problems rather than solving problems in decision making.

Accordingly, this research is a research done collaboratively between counselor and teachers of civic education subject. The reasons of why civic education was used in this study because civic education is character education, in which in the context of guidance and counseling, the character development is the part of self and social guidance program. In relation to citizenship education, the results of the study Ahraria, et al. (2016) exhibited that critical thinking skills are influenced by citizenship skills and attitudes. The results of Reichert's study (2019) showed that 'encouraging students to think critically' is one of the three goals of Citizenship Education selected by teachers from the eleven countries studied. As Jansen et al. (2019) teachers do play an important role in encouraging students' critical thinking skills, but few of them know how to develop critical thinking skills in learning.

Critical thinking is one of the parts of character education that becomes the mission of civic education and self and social development program in guidance and counseling. Thus, in this case, the counselor has a central role as a leader, initiator, facilitator, and consultant (Handarini, 2017). There is a correlation between the role and responsibility of counselors as the member of learning community that has unique values, knowledge, skills, and responsibilities with teachers to enrich the teaching and learning practice (Collin, et al, 2013). One of the collaborations of teachers and counselors is the implementation of a learning strategy that can be used to develop critical thinking.

The experts wrote that critical thinking can be fostered with strategies that serve controversial topics (Santrock, JW, 2007), problem-based learning, social interaction, technology-enriched learning environment, and extra-curricular activities (Duran, M \& Sendag, S, 2012), problem-solving on the real world where it is possible that more than one information and solutions obtained and problem-based approach (Masek, \& Yamin, 2011; Awang, \& Ramly, 2008). PBL is considered as an appropriate approach because it is supported by diverse learning theories (cognitivism and constructivism) and the research results proved that intervention model effectively encouraged a higher-level thinking, knowledge construction, autonomous, and collaborative learning (Tan, 2009). 
Fabiana (2015) wrote that the determinants of critical or uncritical thinking in Indonesia are group climate, motivation or individual attitudes. According to Yew, Goh (2016) wrote that PBL is an effective learning approach especially for the retention of long-term knowledge applications.

The research of Kusumaningtias, et al. (2013) reported that there was a difference in the mean score of students critical thinking taught by using PBL combined with NHT strategy than using conventional learning. The research results of Dwijananti \& Yulianti (2010) also emphasized that the problem-based learning model could develop critical thinking in the ability to clarify, assume, predict, hypothesize, evaluate, analyze, and conclude. The increase in the mean score of the students' critical thinking went alongside with the increase in the number of students categorized as very critical and critical in the critical thinking ability category hierarchy. According to Muniroh, et al. (2016) through PBL, students are more motivated by themselves when presented with an interesting problem, they have a self-satisfaction and pressure when doing the given assignment. The implementation of the PBL model encourages collaborative and constructive learning. Thus, students who are more engaged in problem-based learning showed a better attitude in knowledge assessment. But if the teacher wants to use PBL, special attention must be given to the discussion phase and the use of various problem triggers (Servant-Miklos, 2018).

Other research results also showed that PBL could be used for high school students or bachelors (Sulaiman, 2013) and was able to increase self-directed learning (Hmelo-Silver, 2004) and self-regulated learning (Sungur \& Tekkaya, 2006) as well as students' academic engagement (Muniroh et al., 2016). Next, several studies wrote that the predictors affecting the correlation between the problem-based approach and critical thinking are age, gender, academic achievement, and education background (Awang \& Ramly, 2008). The factors of communication skills, interpersonal skills, level of participation, gender stereotypes and teacher individuality influence student feedback in PBL (Yew, Goh, 2016). Besides, the school environment, teachers' characters, and students' attitude significantly determine the encouragement of critical and creative thinking and students' problem-solving (Hamza \& Griffith, 2006). Through the implementation of an appropriate learning strategy, it is expected that vocational school students can obtain learning experience to become a critical individuals characterized by behaving honestly, facing the controversial problems as an interesting challenge, assessing based on proofs, interested with others' ideas, having self-control, and controlling the emotion and thinking before acting (Ruggiero, V, 2012).

\section{Research Method}

This research used quasi-experiment design with a non-equivalent pre-test and post-test control group design. The character of research findings with a quasiexperiment design was more suitable to be applied in the real administered learning (Creswell, 2014). The subjects of this research were selected by using cluster random sampling technique based on the area or certain groups. Thus, the subject sampling in this research was done by two steps; they determined the 
schools as the setting of the research, and the classes as the experimental and control classes.

Based on the needs analysis, the efficiency and effectivity, it was determined that one of the state vocational schools in Malang city that was SMK Negeri 10 Malang as the setting of the research. The determination of this school as the research setting is because this school had the majors needed to develop the critical thinking like Computer and Networking Technology major, the guidance and counseling teachers in this school were actively pioneering the collaborative model with both internal and external parties. The internal collaboration was done with the subject teachers, specifically normative subjects like civic education, and technically, the civic education teachers in this school had not applied PBL in accordance with the theory and its stages. PBL was more interpreted as discussion activities and presentations from the assignments on student books. Next, the determination of experimental and control classes began determining the major that needed more critical thinking. Based on the consideration of guidance and counseling teacher and subject teachers, the major as the research subjects was Computer and Networking Technology (Teknik Komputer Jaringan/TKJ) major consisted of 6 classes. From 6 classes, TKJ 1 and TKJ 3 were chosen.

The basic consideration for the selection of these two classes was methodologically, both of these classes stated that they had never received a problem-based learning strategy (based on survey results on students readiness in following PBL attachment 4.2), both of these classes had a mean value of exams which were given in the civic education that was relatively the same namely 8.73 for TKJ 1 and 8.78 for TKJ 2. Taking the value of civic education because the subjects and instruments developed with respect to critical thinking skills are the civic education subject, both of these classes had the same period of civic education lesson i.e. every Monday at 9.45 to 11.05 for TKJ 1 and 11.05 up to 12.25 for TKJ 3 so that the research process could run naturally without much time consuming, the number of students in these two classes above was 32 which was qualified as samples for experimental research, and guidance and counseling noted both classes were relatively cooperative and not too much trouble compared to other classes, making it easier to work together in this research activity. Based on these considerations, 33 students from TKJ 1 as subjects in the experimental group would be subjected to problem-based learning and 33 TKJ 3 students as a control group that would get the conventional learning treatment.

Critical thinking skills are presented in five dimensions namely skills to conclude based on specific facts (inference), skills to recognize the assumptions (recognition of assumptions), skills to interpret (interpretation), skills to deduct conclusions based on the theory or general statements (deduction), and skills to evaluate the reasons (evaluation of argument). The control variable would be controlled related to this research were teachers' teaching ability, material coverage that would be taught, the timetable of the lessons, the implementation of the instruments. For that matter, the researcher constructed the critical 
thinking instruments and two handbooks namely the Problem-Based Learning Handbook and the conventional Learning Handbook of which its validity and reliability were already tested.

Both critical thinking instruments and handbooks were developed based on civic education. The handbook consisted of civic education lesson plan was arranged as the guidance in conducting the research. The data collection instruments in the research were employed by giving the pre- and post-tests instruments constructed for experimental and control group. Both groups did regular teaching and learning activities, but the problem-based learning was given to the experimental group which was TKJ 1. During the process, the researcher and the observer observed the teaching and learning activities carried out by the teacher and noted the activities of critical thinking done by the students using the observation sheets. The results of the observation were evaluated once a week to assure the consistency of their behavior based on the main objectives. Furthermore, the data analysis was undertaken by reporting descriptive statistics measured or observed previously, the data collection in preand post-test in means, standard deviation, range (Creswell, 2010), and t-test to observe the difference.

\section{Results and Discussion}

The data resulted from the pre-test consisting of prior competence of each group were used to find out the difference between the treatment and control classes. The result of $t$-test on pre-test score of critical thinking showed that $F$ count score with Equal Variance Assumed as much as 2.444 with the significance level of 0.120 , and $t_{\text {count }}$ result was 0.139 with $\mathrm{df}$ of 128 on the significance level of 0.890 . The data showed the $t_{\text {count }}(0.1390)$ was smaller than $t_{\text {tabel }}(1.978)$. Accordingly, it means that there was no significant difference between the students taught with problem-based and conventional learning strategies. In addition, before the treatment, there was no difference in the critical thinking in students taught using problem-based and conventional learning strategies.

Next, the experimental group was given the problem-based strategy treatment and followed by a post-test. The post-test was also given to the control group with conventional strategy. The test results of the difference in the vocational school students' critical thinking treated using problem-based (PBL) and conventional learning strategy in civic education lesson based on their pre- and post-test in each domain are shown in Table 1.

Table 1. The Test results of the difference in the critical thinking on pre- and post-test for problem-based learning strategy (pbl) implementation in civic education lesson.

\begin{tabular}{|l|l|l|l|l|l|}
\hline Critical thinking skills & $\mathbf{N}$ & $\begin{array}{l}\text { Pre-test } \\
\text { means }\end{array}$ & $\begin{array}{l}\text { Post-test } \\
\text { means }\end{array}$ & t-value & Sig. \\
\hline Inference & 33 & 4.88 & 4.97 & -0.620 & 0.540 \\
\hline Recognition of assumptions & 33 & 3.36 & 3.64 & -3.464 & 0.002 \\
\hline Deduction & 33 & 5.03 & 5.33 & -3.730 & 0.001 \\
\hline Interpretation & 33 & 8.91 & 9.18 & -2.502 & 0.018 \\
\hline Evaluation of argument & 33 & 4.33 & 5.61 & -10.844 & 0.000 \\
\hline
\end{tabular}


Based on the table above, it explaines that the difference in the critical thinking on the inference dimension or making conclusion shown by the result of the preand post-test with the significance score of 0.540 was higher than a as much as $5 \%$. The results showed that there was no difference in the critical thinking on inference dimension between pre-test and post-test in implementing the problem-based learning strategy (PBL) with the pre-test mean score of 4.88 and post-test score of 4.97. The difference in critical thinking on the dimension of recognition of assumptions or introducing the assumptions having the significance score of 0.002 smaller than a as much as $5 \%$, the results showed that there was a difference of the critical thinking on the dimension of recognition of assumptions with the score of 3.36 and the post-test of 3.64. Meanwhile, the difference in critical thinking skill on the dimension of deduction between pretest and post-test in PBL application has a significance value of 0.001 which showed a smaller result than a of $5 \%$. These results also showed that there was a difference in critical thinking skills in the dimensions of deduction where the average pre-test value was 5.03 and the post-test value was 5.33 . The difference in critical thinking skills on the Interpretation dimension or interpreting between pre-test and post-test has a significant value of 0.018 less than a as much as $5 \%$. These results showed that there was a difference in critical thinking skills in the interpretation dimension between pre-test and post-test with the average pretest value of 8.91 and the post-test value of 9.18. The difference in critical thinking skills in the dimensions of evaluation of arguments has a significance value of less than 0.000 smaller than a $5 \%$. These results also showed that there was a difference in critical thinking skills in the dimension of evaluation of argument with the average pre-test value of 4.33 and the post-test value of 5.61.

Meanwhile, the difference in critical thinking skills shown by pre-test results and post-test on the application of conventional learning strategy is presented in Table 2 .

Table 2. The test results of the difference in the critical thinking on pre- and post-test for conventional learning strategy implementation in civic education lesson.

\begin{tabular}{|l|l|l|l|l|l|}
\hline Critical Thinking Skills & $\mathbf{N}$ & $\begin{array}{l}\text { Conventional } \\
\text { Pretest Mean }\end{array}$ & $\begin{array}{l}\text { Conventional } \\
\text { posttest Mean }\end{array}$ & t-value & Sig. \\
\hline Inference & 33 & 4.00 & 5.21 & -7.509 & 0.000 \\
\hline Recognition of assumptions & 33 & 2.91 & 3.36 & -3.136 & 0.004 \\
\hline Deduction & 33 & 4.64 & 5.00 & -1.712 & 0.097 \\
\hline Interpretation & 33 & 8.18 & 8.52 & -1.627 & 0.113 \\
\hline Evaluation of argument & 33 & 3.79 & 4.91 & -6.294 & 0.000 \\
\hline
\end{tabular}

Based on the table, it is explained that the differences in critical thinking skills in the inference dimension between pre-test and post-test in the application of conventional learning strategy had a significant value of 0.000 smaller than a of $5 \%$. These results indicated that there was a difference in critical thinking skills on the inference dimension between the pre-test and the post-test in the application of conventional learning strategy with the average pre-test score of 4.00 and the post-test score of 5.21. The difference in critical thinking skills in the recognition of assumptions dimension between pre-test and post-test had a significance value of 0.004 that was smaller than a of $5 \%$. These results showed 
that there was a difference in critical thinking skills in the recognition of assumptions dimension with the pre-test mean score of 2.91 and the post-test mean score of 3.36. The difference in critical thinking skills in the dimension of deduction had a significance value of 0.097 greater than a of $5 \%$. These results indicated that there was no difference in critical thinking skills in the dimensions of deduction between pre-test and post-test with a pre-test mean score of 4.64 and a post-test mean score of 5.00. The difference in critical thinking skills in the interpretation dimension had a significance value of as much as 0.113 which was greater than a of $5 \%$. These results also showed that there was no difference in critical thinking skills on the interpretation dimension with a pre-test average of 8.18 and a post-test average of 8.52. The difference in critical thinking skills on the dimension of evaluation of argument between pre-test and post-test in the application of conventional learning strategy had a significance value of 0.000 smaller than a $5 \%$, this result showed that there were differences in critical thinking skills on the dimensions of evaluation of argument with the value of pre-test mean of 3.79 and the post-test mean of 4.91 .

Then t-test was conducted to know the difference in critical thinking skill between the experimental group consisted of the students who got the problembased learning strategy and the control group was the group of students who got the conventional learning strategy. The test results are described as follows.

Table 3. The test results of difference in the critical thinking between experimental and control groups

\begin{tabular}{|l|l|l|l|l|l|}
\hline Research Variables & N & $\begin{array}{l}\text { Means of } \\
\text { Problem-Based } \\
\text { Learning } \\
\text { Strategy }\end{array}$ & $\begin{array}{l}\text { Means of } \\
\text { Conventional } \\
\text { Learning } \\
\text { Strategy }\end{array}$ & t-value & Sig. \\
\hline Critical Thinking Skills & 33 & 50.79 & 28.79 & 16.874 & 0.000 \\
\hline
\end{tabular}

Based on the above table, it was found that the mean of problem-based learning strategy was 50.79, while the mean value of conventional learning strategy was 28.79 and the difference in critical thinking skills taught with problem-based learning strategy and conventional learning strategy with the $t$-value of 16.874 and significant at the 0.000 level. These results showed that there were differences in critical thinking skills taught by problem-based learning strategies with conventional learning strategies. The results of this study were similar to the findings of Widyatiningtyas, et al. (2015) who examined the influence of PBL on critical thinking skills in the field of mathematics in high school students in Bandung. The results also concluded that students who were taught using problem-based learning had more critical thinking than students who were taught using conventional learning. Similarly, the results of Sulaiman's (2011) research showed that there was a difference in the influence of PBL strategy use with the conventional strategy to critical thinking skills in physics lesson in apprenticeship students in Malaysia.

This study showed that the magnitude of the difference in the influence of critical thinking skills between students who were taught using a problem-based 
learning strategy with students taught through conventional learning strategy occurred almost in all aspects of critical thinking which included inference, recognition of assumptions, deduction, interpretation, and evaluation of the argument. Conventional learning had no effect on the development of the aspects of deduction and interpretation of critical thinking skills. However, in the inference aspect, the use of conventional learning strategy was greater than the use of problem-based learning strategy. This was possible because in making conclusions it takes more material contents of learning and conventional learning strategy was intended so that students could master the material optimally.

However, in the recognition of assumptions aspect, a problem-based learning strategy was greater than the conventional learning strategy. Similarly, it was also greater in the aspects of deduction, interpretation, and evaluation of the argument. The magnitude of the influence of problem-based learning strategies to these four aspects is inseparable from the characteristics of PBL, namely PBL is a series of student activities in which students not only listen, note, and memorize but encourage students actively in thinking, communicating, searching, and processing data, and finally concluded, PBLs place the problem as a key of learning activity, and solving problems is done by thinking scientifically that is deductive and inductive thinking process (Sanjaya, W., 2008). This happens because students can access prior knowledge and lead to a deep understanding, understanding curiosity, and natural imagination in capturing real-world problems, encouraging high-level achievement and thinking skills (critical and creative thinking) because these skills require them to be able to analyze, evaluate and synthesize information from various sources (Arends, D. \& Kilcher, A., 2010).

Based on the theoretical frameworks and the results of the study, there are at least three reasons for problem-based learning strategies that can improve students' critical thinking skills. The first major focus in problem-based learning is a real problem that challenges students to think. According to Santrock (2007), one way to encourage youngsters to think critically is to present controversial topics that allow more than one answer to be discussed. It is because students who learn through problem-solving experiences get lessons about the strategy and thinking (Hmelo-Silver, 2004). In contrast to other learning strategies, problems in problem-based learning strategies are open-ended issues in which the answer to the problem is uncertain (Sanjaya, 2008). The problem is felt in the form of anxiety, complaints or discomforts that are not sourced only on books but on certain events that occur around us. When students attempt to solve problems, then that is where thought is needed (Masek \& Yamin, 2011). Presenting real problems in everyday life allows students to discover new knowledge that challenges them in finding solutions. Students' ability to find alternative solutions through the use of knowledge, arguments, and judgment of ideas suggests critical thinking (Birgili, 2015). It is in line with the study results of Alivernini \& Manganelli (2011) who wrote that the open class climate for discussion significantly increased citizenship knowledge. 
Second, critical thinking elements can be elaborated in the stages of problembased learning. Krulick \& Rudnick (1995) revealed that critical thinking includes testing, questioning, linking, evaluating, collecting, organizing, remembering, identifying, and analyzing information and drawing conclusions from the data and information gathered. The elements are elaborated through the stages of problem-based learning activities that include student orientation to the problem, exploration of initial knowledge, organizing students to learn, making inquiries, producing and presenting the work, analyzing and evaluating the problem-solving process, assessing and reflecting on the learning process. In this research, the elaboration of critical thinking skills was arranged in detail and systematically in the book of research treatment that has been prepared (Suarniati, 2018).

Third, a problem-solving strategy is a series of student learning activities that involves skills in finding and processing various information or data, thinking, cooperating and communicating not just listening, taking notes and memorizing. The results of this study are in line with the findings of Suarniati, et al. (2019) who wrote that PBL can improve the ability to express opinions. The series of activities enable students to build their own knowledge and understanding in understanding themselves and their environment as a lifelong learning process in the midst of increasingly complex issues. Birgili's (2015) study results also concluded that problem-solving strategies can improve not only critical thinking skills, but also creative thinking. Creative and critical thinking complement each other to produce the quality of innovation and sustainability of education. The presentation proves that problem-based learning strategies offer the potential to assist students in developing a flexible understanding and lifelong learning skills. This is because the problem-based learning strategy is designed to help students build a broad and flexible knowledge base, develop effective problemsolving skills, develop lifelong learning skills, become effective collaborators, and develop intrinsic motivation for learning (Hmelo-Silver, 2004). With this capacity, there is a strong foundation that supports the contribution of PBLs to high-level thinking skills, especially critical thinking skills.

Another finding of this research is related to counseling teachers' collaboration and counseling with civic education subject teachers. Collaboration conducted by civic education subject teachers with guidance and counseling teachers resulted in useful discussions in dealing with student problems. Lunenburg (2010) wrote that one of the aims of guidance is to help teachers to solve students' problems, provide advice to the teachers about the use of counseling techniques and assist the teachers in professional development. The difficulty was often found in handling the students' problems due to the lack of information or data required. For example, the counseling teachers noted that there were students in that class who felt inferior and were embarrassed to speak. In the teacher's view, the students were certainly passive in learning and could not express her ideas. However, after guidance and counseling teachers were involved in this learning activity, it was found that the students could also express their ideas clearly and fluently. Based on this data, guidance and counseling teachers could make more informed decisions for handling student problems. Hidayah (2012) wrote that counselors are expected to work hand in 
hand and complement each other with teachers who use subject matter as a service context to facilitate student self-development.

\section{Conclusions}

Based on the discussions above, it can be concluded that there is a significant difference between the uses of problem-based and conventional learning strategy on the vocational school students' critical thinking in aspects of inference, recognition of assumptions, deduction, interpretation, and evaluation of the argument. Based on the discussion results, it is found that the difference happened due to first, the main focus of problem-based learning was the real problem that challenged the students to think. Second, critical thinking elements can be elaborated on the stages of problem-based learning. Third, the problemsolving strategy is the series of students' learning activities that involved skills in finding and managing the information and data, thinking, collaborating and communicating, not only listening, taking notes, and memorizing. Even though the use of problem-based learning strategy is proven to affect the vocational school students' critical thinking, in carrying out the activities are not easy moreover if related to the other soft skills development. Thus, subject teachers need to collaborate with the counselors in planning, administration, and evaluation of the teaching and learning.

\section{References}

Ahraria, S., \& Zeinab, A. W. (2016). Deepening critical thinking skills through civic engagement in Malaysian higher education. Thinking Skills and Creativity, 22, 121128. https://doi.org/10.1016/j.tsc.2016.09.009

Alivernini, F., \& Manganelli, S. (2011). Is there a relationship between openness in classroom discussion and students' knowledge in civic and citizenship education? Procedia - Social and Behavioral Sciences, 15, 3441-3445. https:// doi.org/10.1016/j.sbspro.2011.04.315

Arends, D., \& Kilcher, A. R. (2010). Teaching for student learning: Becoming an accomplished teacher. Oxford, UK: Routledge. https:// doi.org/10.4324/9780203866771

Arslan, S. (2012). The Influence of Environment Education on Critical Thinking and Environmental Attitude. Procedia - Social and Behavioral Sciences, 55, 902-909. https://doi.org/10.1016/j.sbspro.2012.09.579

Awang, H. \& Ramly, I. (2008). Creative Thinking Skill Approach Through ProblemBased Learning: Pedagogy and Practice in the Engineering Classroom. International Journal of Educational and Pedagogical Sciences, 2(4), 334-339. Retrieved from: https:// publications.waset.org/15369/pdf

Bezanilla, M. J., Nogueira, D. F., Poblete, M., \& Domínguez, H. G. (2019). Methodologies for teaching-learning critical thinking in higher education: The teacher's view. Thinking Skills and Creativity, 33(100584). https://doi.org/10.1016/j.tsc.2019.100584

Birgili, B. (2015). Creative and Critical Thinking Skills in Problem-based Learning Environments. Journal of Gifted Education and Creativity, 2(2), 71-80. https://doi.org/ 10.18200/JGEDC.2015214253

Creswell, J. W. (2014). Research Design: Qualitative, Quantitative and Mixed Methods Approaches(Fourth edition). Sage publications Inc.

Colin,H., Alison B., Judith G., Kathie C., \& Elmarie Kotzé (2013). School Counsellors and the Key Competencies The Difference that Makes the Difference. School Counsellors and the Key Competencies, 33(1), 1-15.

Duran, M., \& Sendag, S. (2012). A Preliminary Investigation into Critical Thinking Skills of Urban High School Students : Role of an IT / STEM Program. Creative Education, 
3(2), 241-250. https://doi.org/10.4236/ce.2012.32038

Dwijananti, P., \& Yulianti, D. (2010). Pembelajaran Problem Based Instruction Pada Mata Kuliah [Problem Based Learning In Subjects]. Jurnal Pendidikan Fisika Indonesia, 6, 108114. Retrieved from http://journal.unnes.ac.id.

Fabiana, G. (2015). Non-critical thinking: What if not thinking? Procedia - Social and $\begin{array}{lllll}\text { Behavioral Sciences, } & \text { 186(2015), } & 699 & - & 703 .\end{array}$ https://doi.org/10.1016/j.sbspro.2015.04.088

Hamza, M., \& Griffith, K. (2006). Fostering problem-solving \& creative thinking in the classroom: cultivating a creative mind. National Forum of Applied, 19(3), 1-30.

Handarini, D. M. (2017). Peran Konselor Dalam Membentuk Generasi Muda Berkarakter [The Role of Counselors in Forming Young Generation Character]. Prosiding SNBK (Seminar Nasional Bimbingan dan Konseling), 1(1), 1-8.

Harell, K. F. (2019). Deliberative decision-making in teacher education. Teaching and Teacher Education, 77, 299-308. https://doi.org/10.1016/j.tate.2018.10.015

Hidayah, N. (2012). Process-Audit dalam Penyelenggaraan Pendidikan Akademik Jenjang S-1 Bimbingan dan Konseling [Process-Audit in Organizing Academic Education for Undergraduate Guidance and Counseling]. Jurnal Pendidikan Dan Pembelajaran (JPP), 17(2), 129-139.

Hmelo-Silver, C. E. (2004). Problem-based learning: what and how do students learn? Education Psychology Review, 16(3), 235-266. https://doi.org/10.1023/B:EDPR.0000034022.16470.f3

Janssen, E. M., Mainhard, T., Buisman, R. S. M., Verkoeijen, P. P. J. L., Heijltjes, A. E. G., Peppen, L. M., \& Gog, T. (2019). Training higher education teachers' critical thinking and attitudes towards teaching it. Contemporary Educational Psychology. 58, 310-322. https:// doi.org/10.1016/j.cedpsych.2019.03.007

Kusumaningtias, A. (2013). Pengaruh Problem Based Learning dipadu Strategi Numbered Heads Together terhadap Kemampuan Metakognitif, Berpikir Kritis, dan Kognitif Biologi Siswa Kelas XI SMA Negeri 5 Malang [The effect of Problem Based Learning combined with Numbered Heads Together Strategy on Metacognitive Ability, Critical Thinking, and Biological Cognitive of Class XI Students of SMA Negeri 5 Malang] (Master's thesis). University of Malaya, Kuala Lampur, Malaysia.

Lunenburg, F. C. (2010). School Guidance and Counseling Services. Schooling, 1(1), 1-9.

Masek, A., \& Yamin, S. (2011). The Effect of Problem Based Learning on Critical Thinking Ability: A Theoretical and Empirical Review. International Review of Social Sciences and Humanities, 2(1), 215-221.

Muniroh, A., Sudana, I. N., Hitipeuw, I., \& Hidayah, N. (2016). Peningkatan Academic Engagement Siswa melalui Penerapan Model Problem Based Learning di Madrasah Tsanawiyah [Improvement of Student Academic Engagement through the Implementation of Problem Based Learning Models in Tsanawiyah Madrasas]. Jurnal Pendidikan Humaniora, 4(1), 36-52.

Neumark, D., \& Ann, A. (2003). What Do We Know About the Effect of School to Work; Case Study of Michigan. Journal of Vocational Education Research. 28(1), 59-84.

O. S. Tan. (2009). Problem-Based Learning and Creativity. Singapore: Cenage Learning Asia Pte Ltd.

Prayitno, A. (2016). The Characteristics of Students' Refractive Thinking about Data. Proceedings of the $3^{\text {rd }}$ International Conference On Research, Implementation And Education Of Mathematics And Science (ICRIEMS) (pp. 29-38). Yogyakarta, Indonesia.

Prayitno, A., \& Suarniati, N. W. (2017). Construction Students' Thinking in Solving Mathematics Problem Using Cognitive Map. Global Journal of Pure and Applied Mathematics, 13(6), 2735-2747.

Reichert, F., \& Torney-purta, J. (2019). A cross-national comparison of teachers' beliefs about the aims of civic education in 12 countries: A person-centered analysis. 
Teaching and Teacher Education, 77, 112-125.

https://doi.org/10.1016/j.tate.2018.09.005

Ruggiero, V, R. (2012). Beyond Feelings: A Guide to Critical Thinking (9th ed.). New York, NY: McGraw-Hill.

Sanjaya, W. (2008). Strategi Pembelajaran Berorientasi Standar Proses Pendidikan [Standardized Process Education Learning Process]. Jakarta, Indonesia: Kencana Prenada Media Group.

Santrock, J. W. (2007). Remaja [Teenager] (Eleventh edition). Jakarta: Erlangga.

Servant-Miklos, V. F. C. (2018). The Harvard Connection: How the Case Method Spawned Problem-Based Learning at McMaster University. Health Professions Education (2018). https:/ / doi.org/10.1016/j.hpe.2018.07.004

Siegel, H. (2010). Critical Thinking. International Encyclopedia of Education, 6, 141-145.

Solaang, D. (2006). Efek latihan Keterampilan Intelektual Analitik, Sintetik, Praktikal Berdasarkan Teori Intelegensi Triarchic terhadap Kemampuan Pemecahan Masalah secara Kreatif pada Siswa SMP Negeri 4 Malang [Effects of Analytical, Synthetic, Practical Intellectual Skills Training Based on Triarchic Intelligence Theory on Creative Problem Solving Abilities in Students of SMP Negeri 4 Malang] (Master's thesis). Universitas Negeri Malang, Malang, Indonesia.

Suarniati, N. W. (2018). The Development of Learning Tools to Improve Students' Critical Thinking Skills in Vocational High The Development of Learning Tools to Improve Students' Critical Thinking Skills in Vocational High School. IOP Conf. Series: Earth and Environmental Science. 175(2018), 1-7. https:/ / doi.org/10.1088/1755-1315/175/1/012095

Suarniati, N. W., Kristianingsih, G. N. S., \& Suprastowo, A. (2019). Penggunaan Strategi Pembelajaran Berbasis Pemecahan Masalah Untuk Meningkatkan Kecakapan Menyampaikan Pendapat Siswa Smpk Wignya Mandala Tumpang [The use of Problem Solving-Based Learning Strategies to Improve the Skills of Conveying Opinions of Junior High School Students with Mandala Overlapping Wigs]. Likhitaprajna. 21(1).

Sulaiman, F. (2013). The Effectiveness of PBL Online on Physics Students ' Creativity and Critical Thinking: A Case Study at Universiti Malaysia Sabah. International Journal of Education and Research, 1(3), 1-18.

Sungur, S., \& Tekkaya, C. (2006). Effects of Problem-Based Learning and Traditional Instruction on Self-Regulated Learning. The Journal of Educational Research, 99(5), 307-320. https:/ / doi.org/10.3200/JOER.99.5.307-320

Widyatiningtyas, R., Kusumah, Y. S., Sumarmo, U., \& Sabandar, J. (2015). The Impact of Problem-based Learning Approach to Senior High School Studentes' Mathematic Critical Thinking Ability. Journal of Mathemathics Education, 6(2), 30-38.

Yew, E. H. J., \& Goh, K. (2016). Problem-Based Learning: An Overview of its Process and Impact on Learning. Health Professions Education, 2(2), 75-79. http:/ /dx.doi.org/10.1016/j.gpe.2016.01.004

Yin, K. Y., Abdullah, A. G. K., \& Alazidiyeen, N. J. (2011). Collaborative Problem Solving Methods towards Critical Thinking. International Education Studies, 4(2), 58-63. https:/ / doi.org/10.5539/ies.v4n2p58 